\title{
Clinicopathological Aspects of Small Cell Neuroendocrine Carcinoma of the Uterine Cervix: a Multicenter Retrospective Study and Meta-Analysis
}

\author{
Fan Xu Jing Ma ${ }^{a, d}$ Hongyan $\mathrm{Yi}^{\mathrm{a}}$ Huiquan $\mathrm{Hu}^{\mathrm{b}}$ Liangsheng Fan ${ }^{\mathrm{c}}$ \\ Peng Wu ${ }^{e}$ Xiaojing Chen ${ }^{a}$ Xiangguang $W^{a, c}$ Lan $\mathrm{Yu}^{c}$ Hui Xing ${ }^{f}$ \\ Wei Wang ${ }^{\mathrm{a}, \mathrm{c}}$
}

\begin{abstract}
aDepartment of Obstetrics and Gynecology, Nanfang Hospital/The First School of Clinical Medicine, Southern Medical University, Guangzhou, 'Department of Obstetrics and Gynecology, Nanchong Central Hospital, North Sichuan Medical University, Nanchong, 'Department of Obstetrics and Gynecology, The First Affiliated Hospital, Guangzhou Medical University, Guangzhou, dDepartment of Obstetrics and Gynecology, People's Hospital of Three Gorges University, Yichang, ${ }^{\circ}$ Cancer Biology Research Center, Tongji Hospital, Tongji Medical College, Huazhong University of Science and Technology, Wuhan, 'Department of Obstetrics and Gynecology, Xiangyang Central Hospital, Hubei University of Arts and Science, Xiangyang, China
\end{abstract}

\section{Key Words}

Cervical cancer $\cdot$ Small cell neuroendocrine carcinoma $\cdot$ Survival rate $\bullet$ Prognostic factor

\begin{abstract}
Background/Aims: To evaluate the clinicopathologic aspects of small cell neuroendocrine carcinoma of the uterine cervix (SCNEC). Methods: A retrospective review of 40 patients with SCNEC in 3 hospitals from 2009 to 2015 was conducted to assess the survival rates and examine the associations between clinicopathological variables and overall survival (OS). A meta-analysis of 22 studies containing 1901 patients was also conducted to further confirm the results. Results: In the clinical group of 40 patients, the 5-year OS rate was $20 \%$. Advanced International Federation of Gynecology and Obstetrics (FIGO) stage and radiation therapy (RT) were associated with poor survival. However, radical surgery was associated with prolonged survival. In the meta-analysis of 1901 patients, the 2-year disease-free survival (DFS) rate, 5-year DFS rate, 2-year OS rate, 3-year OS rate and 5-year OS rate of SCNEC were $48 \%$, $35 \%, 62 \%, 35 \%$, and 35\% respectively. Advanced FIGO stage, larger tumor size, lymph node metastasis $(\mathrm{LNM})(+)$, lymphovascular space involvement (LVSI) (+), parametrial involvement (PI) $(+)$, depth of stromal invasion (DSI) $>2 / 3$, and RT were associated with poor survival. However, a chemotherapy regimen similar to that for small cell lung cancer was associated

F. Xu, J. Ma and H. Yi contributed equally to this work.

\begin{tabular}{ll}
\hline Wei Wang & Department of Obstetrics and Gynecology, Southern Medical University \\
and Hui Xing & Guangzhou, Guangdong 510515 (China) \\
& E-Mail smugowwang@126.com; huixing1969@163.com
\end{tabular}
\end{abstract}




\section{Cellular Physiology Cell Physiol Biochem 2018;50:1113-1122 \begin{tabular}{ll|l} 
DOl: 10.1159/000494538 & O 2018 The Author(s). Published by S. Karger AG, Basel \\
www.karger.com/cpb
\end{tabular} \\ Xu et al.: Clinicopathological Aspects of SCNEC}

with prolonged survival. Conclusion: Advanced FIGO stage, larger tumor size, LNM (+), LVSI $(+), \mathrm{DSI}>2 / 3, \mathrm{PI}(+)$, and RT were independent predictors of poor prognosis of SCNEC. Radical surgery combined with a chemotherapy regimen similar to that of small cell lung cancer may be a potential therapeutic approach for SCNEC.

\section{Introduction}

Small cell neuroendocrine carcinoma of the uterine cervix (SCNEC) is a rare disease that accounts for less than $5 \%$ of all uterine cervical carcinomas [1]. Compared with squamous cell carcinoma (SCC) or adenocarcinoma (ADC) of the cervix, SCNEC is more likely to be an aggressive type that develops distant metastases, even in its early stages [2]. However, past studies have shown disagreement in the 5-year overall survival (OS) rate of SCNEC. The lowest rate was reported by Li et al. as 4\% [3] and the highest was reported by Chen et al. as $51 \%[4]$.

Because of the low incidence of SCNEC, previous studies were mostly clinical case reports or case series, making it difficult to draw conclusions on overall management [5]. In addition to FIGO stage [6,7], several potential prognostic factors [2, 8-14] including age, tumor size, lymphovascular space involvement (LVSI), lymph node metastasis (LNM), depth of stromal invasion (DSI), parametrial involvement (PI), and treatment modality have been shown to influence survival, though not in all studies. For example, Lee et al. [15] reported that in patients with stage IB-IIA SCNEC, neoadjuvant chemotherapy tended to improve 5-year survival. However, the number of patients was limited. Because there are no published guidelines for the prognosis and treatment of SCNEC to date, knowledge regarding the treatment regimens and factors for survival is still fragmentary.

Knowledge of potential prognostic factors is important for the optimal selection of treatment modalities, monitoring of treatment response, and planning of follow-up. Although there is a large body of literature on prognostic factors for cervical cancer, we are unaware of studies examining the magnitude of prognostic factors according to histological type among patients with SCNEC, SCC, or ADC. Therefore, the aim of this cohort study was to generate an assessment of the survival rates, clinicopathological variables and treatment strategies associated with prognosis of SCNEC patients from 3 hospitals in China over a 6-year period and from the PUBMED database over a 22-year period.

\section{Materials and Methods}

\section{Patients}

Forty patients with SCNEC from 3 hospitals (Nanfang Hospital, Southern Medical University; Tongji Hospital, Huazhong University of Science and Technology; Xiangyang central hospital, Hubei University of Arts and Science) who were diagnosed from January 2009 to October 2015 were enrolled in this study. All 40 patients were definitively diagnosed by two pathologists after a second examination of specimen slides. The retrospective part of this study was approved by the Ethics Committees of Nanfang Hospital, Tongji Hospital, and Xiangyang Central Hospital respectively. Because of the retrospective study design, informed consent could not be obtained from the patients. Instead of obtaining informed consent from each patient, we posted a notice about the study design and contact information in a public location.

\section{Search strategy}

We searched the PUBMED database from 1995 to 2017 for articles evaluating the effect of SCNEC on any prognostic index of human cancers, including survival, stage at diagnosis, treatment choice, and other factors, such as age, tumor histology, tumor size, FIGO stage, PI, LNM, LVSI, and DSI. Our overall search strategy included terms for cervical cancer ("cervix", "small cell neuroendocrine"), cancer (eg, "carcinoma", "malignant neoplasm"), and prognosis (eg, "mortality", "overall survival rate") and was limited to articles in the English or Chinese language and human studies. We also searched references of included articles. 


\section{Cellular Physiology Cell Physiol Biochem 2018;50:1113-1122 \begin{tabular}{ll|l} 
and Biochemistry & $\begin{array}{l}\text { DOI: 10.1159/000494538 } \\
\text { Published online: 24 October } 2018\end{array}$ & $\begin{array}{l}\text { (c) } 2018 \text { The Author(s). Published by S. Karger AG, Basel } \\
\text { www.karger.com/cpb }\end{array}$
\end{tabular} \\ Xu et al.: Clinicopathological Aspects of SCNEC}

\section{Study selection}

Inclusion and exclusion criteria were as follows: (i) studies with a retrospective design or case series; (ii) studies where the histologic tumor type was SCNEC; (iii) studies that provide data on age, tumor FIGO stage, tumor histology, LNM, tumor size, LVSI, PI, SM, DSI, radiation therapy, chemotherapy, chemotherapy regimen, survival rates, hazard ratio (HR), and 95\% confidence interval (CI) or sufficient survival data; (iv) studies that used similar research methods; (v) studies with 15 or more patients and published in English or Chinese language; and (vi) studies published between January 1995 and August 2017. Regarding exclusion criteria, case series with a sample size of less than 15 patients were excluded and studies published before 1995 were excluded.

Two investigators (Xu Fan and Ma Jing) extracted the data from the studies. All data were verified by internal consistency, and disagreements were resolved by discussion between the two investigators. The meta-analysis part of the study was approved by the Ethics Committee of Nanfang Hospital, Southern Medical University.

\section{Data extraction}

A data extraction form was used to record all the required data from each study. This form included sample size, study region, survival rates, as well as the HRs of prognostic factors such as age, FIGO stage, tumor histology, LNM, tumor size, LVSI, PI, SM, DSI, and treatment strategies.

\section{Statistical analysis}

OS was calculated from the time of initial diagnosis until death; patients who were alive at the last follow-up were censored. Prognostic factors affecting OS were estimated using the Cox proportional hazards model, and HRs of the risk factor were calculated using IBM SPSS version 19.0. All the tests were two-sided, and $\mathrm{P}<0.05$ was considered statistically significant. The meta-analysis was carried out using STATA version 12.0. The effect of risk factors on prognosis was presented as HR with $95 \%$ CI. Overall pooled HR was estimated by calculating the weighted average of the study-specific logarithmically transformed (log) HR and its standard error from the reported results or calculating them directly using the method reported by Tierney et al. [16]. The chi-squared test for homogeneity was performed, and heterogeneity was considered significant when $\mathrm{I}^{2}$ was over $50 \%$ or $\mathrm{P}<0.1$. A random effects model was used for meta-analysis. Publication bias was assessed graphically using funnel plots and regression tests. $\mathrm{P}<0.05$ was considered statistically significant.

\section{Results}

Survival rates and prognostic factors of SCNEC in the clinical group

Demographic characteristics of the patients are shown in Table 1 . Of the 40 patients, $80 \%$ had a pure histological type composed of SCNEC, and 8 patients $(20 \%)$ had a mixed pattern associated with SCC or ADC in addition to the SCNEC component. The median survival time was 19 (ranging from 3-71) months, and the estimated 5 -year OS rate for the clinical group was $20 \%$ (Fig. 1A). We assessed various clinicopathologic

Table 1. Patient characteristics $(\mathrm{N}=40)$. FIGO, International Federation of Gynecology and Obstetrics; LNM, lymph node metastasis; LVSI, lymphovascular space involvement; CT, chemotherapy treatment; DSI, depth of stromal invasion; NAC, neoadjuvant chemotherapy; RT, radiation therapy

\begin{tabular}{|c|c|c|}
\hline $\begin{array}{l}\text { Variables } \\
\text { FIGO stage }\end{array}$ & No. of patients & $\%$ \\
\hline IA & 1 & 2.50 \\
\hline IB & 25 & 62.50 \\
\hline IIA & 9 & 22.50 \\
\hline IIB & 4 & 10.00 \\
\hline IV & 1 & 2.50 \\
\hline \multicolumn{3}{|l|}{ Age, years } \\
\hline Median (range) & $45.5(27 \sim 67)$ & \\
\hline \multicolumn{3}{|l|}{ Tumor size, $\mathrm{cm}$} \\
\hline Median (range) & $3.0(0.5 \sim 6)$ & \\
\hline Pure small cell & 32 & 80.00 \\
\hline $\begin{array}{l}\text { Mixed } \\
\text { LNM }\end{array}$ & 8 & 20.00 \\
\hline \multicolumn{2}{|l|}{ LNM } & \\
\hline Positive & 7 & 17.50 \\
\hline \multicolumn{3}{|l|}{ LVSI } \\
\hline Negative & 35 & 87.50 \\
\hline Positive & 5 & 12.50 \\
\hline \multicolumn{3}{|l|}{ DSI } \\
\hline$>2 / 3$ & 10 & 25.00 \\
\hline$\leq 2 / 3$ & 30 & 75.00 \\
\hline \multicolumn{3}{|l|}{ Treatment } \\
\hline Surgery alone & 2 & 5.00 \\
\hline Surgery+CT & 22 & 55.00 \\
\hline $\mathrm{NAC}+$ Surgery+CT & 7 & 17.50 \\
\hline NAC+Surgery & 2 & 5.00 \\
\hline $\mathrm{NAC}+$ Surgery+CT+RT & 2 & 5.00 \\
\hline $\mathrm{RT}+\mathrm{CT}$ & 2 & 5.00 \\
\hline CT & 1 & 2.50 \\
\hline Surgery+CT+RT & 2 & 5.00 \\
\hline
\end{tabular}




\section{Cellular Physiology Cell Physiol Biochem 2018;50:1113-1122

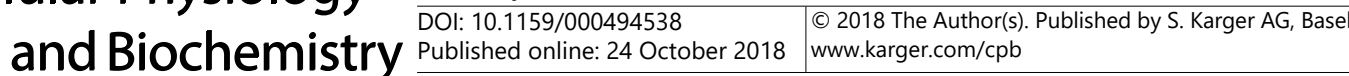

Fig. 1. Overall survival (OS) rates for all patients in the clinical group $(\mathrm{A})$ and the meta-analysis (B). (A): Survival curve of 40 patients from 3 hospitals in the clinical group. (B): Survival curve of 1901 patients from 22 studies in the meta-analysis.

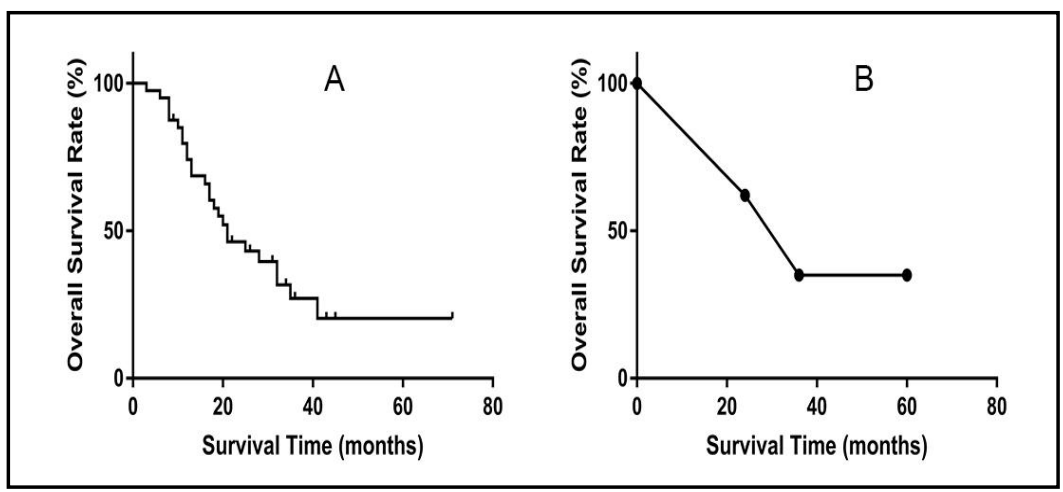

variables to identify prognostic factors for OS and the association between clinicopathological factors and OS (Table 2). In univariate analysis, the pooled HR indicated a significantly shorter OS in SCNEC patients with advanced FIGO stage (HR 2.362, 95\% CI 1.031-5.412) and those who underwent RT (HR 4.361 , 95\% CI 1.57412.081), in contrast to those who underwent radical surgery (SU) (HR 0.111 , 95\% CI 0.0300.416). Other factors did not reach statistical significance including age > 40 (HR 0.699, 95\% CI 0.302-1.622), tumor histology (HR 0.850, 95\% CI 0.317-2.280), LNM (+) (HR 2.329, 95\% CI

Table 2. Univariate and multivariate analysis of survival based on clinicopathologic factors. ${ }^{a}$ Advanced stage (IIA to IV) vs. early-stage (IA to IB2); bixed vs. pure small cell; FIGO, International Federation of Gynecology and Obstetrics; LNM, lymph node metastasis; LVSI, lymphovascular space involvement; CT, chemotherapy treatment; DSI, depth of stromal invasion; NAC, neoadjuvant chemotherapy; RT, radiation therapy; PMCT, postoperative chemotherapy; SU, radical surgery

\begin{tabular}{lcccc}
\hline \multirow{2}{*}{ Variables } & \multicolumn{3}{c}{ Univariate analysis } & \multicolumn{3}{c}{ Multivariate analysis } \\
& Hazard ratio (95\% CI) & $\mathrm{P}$ & Hazard ratio (95\% CI) & $\mathrm{P}$ \\
\hline Age > 40 years & $0.699(0.302-1.622)$ & 0.41 & - & - \\
FIGO stagea & $2.362(1.031-5.412)$ & $<0.05$ & $1.756(0.723-4.269)$ & 0.21 \\
Tumor histologyb & $0.850(0.317-2.280)$ & 0.75 & - & - \\
LNM (+) & $2.329(0.892-6.083)$ & 0.08 & - & - \\
LVSI (+) & $2.648(0.761-9.219)$ & 0.13 & - & - \\
DSI > 2/3 & $0.824(0.328-2.072)$ & 0.68 & - & - \\
Tumor size > 4cm & $0.908(0.380-2.170)$ & 0.83 & - & - \\
NAC (Yes vs. No) & $0.659(0.247-1.760)$ & 0.41 & - & - \\
SU (Yes vs. No) & $0.111(0.030-0.416)$ & $<0.05$ & $0.149(0.036-0.614)$ & $<0.05$ \\
PMCT (Yes vs. No) & $0.880(0.262-2.955)$ & 0.84 & - & - \\
RT (Yes vs. No) & $4.361(1.574-12.081)$ & $<0.05$ & $4.038(1.405-11.606)<0.05$ \\
CT Regimen & & & & - \\
EP vs. TP & $0.809(0.331-2.392)$ & 0.82 & - & - \\
Treatment & & & & - \\
NAC+SU+CT vs. U+CT & $0.595(0.135-2.629)$ & 0.49 & - & - \\
NAC+SU+CT vs. others & $0.453(0.107-1.925)$ & 0.28 & - & - \\
SU+CT vs. others & $0.613(0.280-1.341)$ & 0.22 & - & \\
\hline
\end{tabular}

0.892-6.083), LVSI (+) (HR 2.648, 95\% CI 0.761-9.219), DSI > 2/3 (HR 0.824, 95\% CI 0.3282.072 ), tumor size $>4 \mathrm{~cm}$ (HR $0.908,95 \%$ CI 0.380-2.170), neoadjuvant chemotherapy (Yes vs. No) (HR 0.659, 95\% CI 0.247-1.760), postoperative chemotherapy (PMCT) (Yes vs. No) (HR 0.880, 95\% CI 0.262-2.955), and chemotherapy regimen (EP vs. TP) (HR 0.809, 95\% CI $0.331-2.392$ ). In multivariate analysis, the result showed that the HR for FIGO stage, SU and RT were 1.756 (95\% CI 0.723-4.269, p=0.21), 0.149 (95\% CI 0.036-0.614, $\mathrm{p}=0.08$ ) and 4.038 (95\% CI 1.405-11.606, p<0.05), respectively. 
Table 3. Main characteristics of eligible studies. SCNEC, small cell neuroendocrine carcinoma of the uterine cervix. NECC, neuroendocrine carcinoma of the uterine cervix. NA, not available. OS, overall survival

\begin{tabular}{|c|c|c|c|c|c|c|}
\hline First author & Year & $\begin{array}{l}\text { Source of } \\
\text { patients }\end{array}$ & $\begin{array}{c}\text { No. of } \\
\text { patients }\end{array}$ & Histology & $\begin{array}{c}\text { Clinical period, } \\
\text { year }\end{array}$ & $\begin{array}{l}\text { Median OS time (range), } \\
\text { month }\end{array}$ \\
\hline Chang TC[35] & 1998 & Taiwan & 40 & SCNEC & $1988-1996$ & NA \\
\hline Bermudez $\mathrm{A}^{[36]}$ & 2001 & Argentina & 20 & NECC & 1983-1999 & NA \\
\hline Chan JK[7] & 2003 & USA & 34 & SCNEC & $1979-2001$ & NA \\
\hline $\begin{array}{l}\text { Viswanathan } \\
\text { AN[17] }\end{array}$ & 2004 & USA & 21 & SCNEC & $1980-2000$ & $17(6-209)$ \\
\hline Wang KL ${ }^{[18]}$ & 2006 & Taiwan & 31 & NECC & $1991-2003$ & $24(1.5-143)$ \\
\hline Lee JM[15] & 2008 & Korea & 68 & SCNEC & $1997-2003$ & $54(6-113)$ \\
\hline Kim YM[19] & 2009 & Korea & 20 & SCNEC & $1996-2004$ & $77(43.5-110.5)$ \\
\hline Zivanovic $\mathrm{O}^{[26]}$ & 2009 & USA & 17 & SCNEC & $1990-2007$ & $21(8-46)$ (mean) \\
\hline Huang CY[6] & 2009 & Taiwan & 18 & SCNEC & 1984-2006 & $25(4-143)$ \\
\hline Cohen JG[8] & 2010 & USA & 188 & SCNEC & $1979-2005$ & NA \\
\hline Lee SW[12] & 2010 & Korea & 32 & SCNEC & $1996-2008$ & $30.6(4.6-107.3)$ \\
\hline $\mathrm{Li} \mathrm{JD[3]}$ & 2011 & China & 25 & SCNEC & $1996-2009$ & $20.9(5-62)($ mean $)$ \\
\hline Lan-Fang L[20] & 2012 & China & 43 & SCNEC & $1985-2007$ & $36(5-141.2)$ \\
\hline Tian WJ[13] & 2012 & China & 96 & SCNEC & $1995-2008$ & $45.8(\mathrm{NA})$ \\
\hline Liao LM[10] & 2012 & China & 293 & SCNEC & NA & $23(1-264)$ \\
\hline Intaraphet S[2] & 2013 & Thailand & 130 & SCNEC & $1995-2011$ & $47.8(24.7-200.1)$ \\
\hline Kuji S[37] & 2013 & Japan & 52 & SCNEC & $1997-2007$ & NA \\
\hline Huang $\mathrm{L}^{[38]}$ & 2014 & China & 72 & SCNEC & $1995-2010$ & NA \\
\hline Wang Z[39] & 2015 & China & 32 & SCNEC & $2005-2013$ & $18(7-71)$ \\
\hline Chen TC[4] & 2015 & Taiwan & 110 & SCNEC & $1987-2009$ & 104.5(NA) \\
\hline Lee $S W[11]$ & 2015 & Korea & 102 & SCNEC & $1991-2010$ & $40.7(5.0-218.7)$ \\
\hline Zhou J[40] & 2017 & China & 457 & SCNEC & $1988-2012$ & NA \\
\hline
\end{tabular}

\section{Meta-analysis} published studies

Survival rates and prognostic factors of SCNEC in the meta-analysis

A total of 22 papers including 1901 patients were enrolled in the metaanalysis, and the main features of the eligible studies for aggregation are listed in Table 3. The publication time period of the studies was between 1995 and 2017. The 22 studies originated from three regions: Asia (17), the United States (4), and other (1). We assessed OS rates, and disease-free survival (DFS) rates to present the valid estimation of survival in patients with SCNEC, and got the estimated pooled survival rates as follows (Fig. 2 and 1B): pooled 5-year OS rate 0.35 (95\% CI 0.27-0.44), pooled 3 -year OS rate 0.35 (95\% of Table 4. Meta-analysis of prognostic factors for SCNEC. LVSI, lymphovascular space involvement; LNM, lymph node metastasis; PI, parametrial involvement; DSI, depth of stromal invasion; FIGO, International Federation of Gynecology and Obstetrics; Cs, chemotherapy similar to that for small cell lung carcinoma (PE/VAC); Cns, chemotherapy not similar to that for small cell lung carcinoma

\begin{tabular}{|c|c|c|c|c|c|}
\hline \multirow{2}{*}{$\begin{array}{l}\text { Variables } \\
\text { Age (years) }\end{array}$} & \multicolumn{3}{|c|}{ Number of studies Number of patients Random effects HR(95\%CI) } & \multicolumn{2}{|c|}{$\begin{array}{l}\text { Heterogeneity test } \\
\text { I-squared P-value }\end{array}$} \\
\hline & & & & & \\
\hline$>40$ vs. $\leq 40$ & 6 & 721 & $1.01(0.84-1.21)$ & 0.000 & 0.57 \\
\hline$>45$ vs. $\leq 45$ & 5 & 441 & $1.25(0.81-1.93)$ & 0.504 & 0.09 \\
\hline \multicolumn{6}{|l|}{ Tumor histology } \\
\hline Mix vs. Pure & 9 & 680 & $1.09(0.87-1.36)$ & 0.000 & 0.47 \\
\hline \multicolumn{6}{|l|}{ FIGO stage } \\
\hline II vs. I & 2 & 248 & $1.51(1.04-2.19)$ & 0.000 & 0.46 \\
\hline IIB-IV vs. IA-IIA & 5 & 575 & $1.99(1.34-2.96)$ & 0.606 & 0.04 \\
\hline IB2-IIA vs. IB1 & 5 & 324 & $2.01(1.24-3.25)$ & 0.499 & 0.09 \\
\hline IIA-IV vs. IA-IB2 & 2 & 174 & $2.76(1.59-4.80)$ & 0.000 & 0.55 \\
\hline \multicolumn{6}{|l|}{ Tumor size $(\mathrm{cm})$} \\
\hline$>2$ vs. $\leq 2$ & 5 & 418 & $1.61(1.19-2.19)$ & 0.000 & 0.97 \\
\hline$>4$ vs. $\leq 4$ & 6 & 721 & $1.76(1.09-2.84)$ & 0.572 & 0.04 \\
\hline \multicolumn{6}{|l|}{ LNM } \\
\hline $\begin{array}{l}\text { Positive vs. Negative } \\
\text { LVSI }\end{array}$ & 12 & 1014 & $1.62(1.28-2.05)$ & 0.151 & 0.30 \\
\hline $\begin{array}{l}\text { Positive vs. Negative } \\
\text { PI }\end{array}$ & 10 & 758 & $1.85(1.25-2.72)$ & 0.546 & 0.02 \\
\hline $\begin{array}{l}\text { Positive vs. Negative } \\
\text { Surgical margin }\end{array}$ & 4 & 312 & $2.34(1.52-3.59)$ & 0.000 & 0.70 \\
\hline $\begin{array}{l}\text { Positive vs. Negative } \\
\text { DSI }\end{array}$ & 2 & 178 & $2.02(1.00-4.09)$ & 0.000 & 0.44 \\
\hline$>2 / 3$ vs. $\leq 2 / 3$ & 8 & 741 & $2.15(1.58-2.94)$ & 0.000 & 0.73 \\
\hline \multicolumn{6}{|l|}{ Radiation } \\
\hline Yes vs. No & 5 & 366 & $2.12(1.49-3.02)$ & 0.000 & 0.51 \\
\hline \multicolumn{6}{|c|}{ Adjuvant chemotherapy } \\
\hline \multicolumn{5}{|l|}{ Chemotherapy regimen } & 0.71 \\
\hline Cs vs. Cns & 2 & 136 & $0.42(0.23-0.76)$ & 0.000 & 0.85 \\
\hline
\end{tabular}




\section{Cellular Physiology Cell Physiol Biochem 2018;50:1113-1122 \begin{tabular}{l|l|l} 
DOI: 10.1159/000494538 & Ond 2018 The Author(s). Published by S. Karger AG, Basel \\
wwww.karger.com/cpb
\end{tabular} \\ Xu et al.: Clinicopathological Aspects of SCNEC}

the following clinicopathologic factors were associated with poor OS: advanced FIGO stage (IIA-IV vs. IA-IB2, HR 2.76; IB2-IIA vs. IB1, HR 2.01; IIB-IV vs. IA-IIA, HR 1.99; II vs. I, HR 1.51), larger tumor size ( $>4 v s . \leq 4, \mathrm{HR}, 1.76 ;>2$ vs. $\leq 2$, HR 1.61), LNM (+) (HR 1.62), LVSI (+) (HR1.85), PI (+) (HR, 2.34), DSI > 2/3 (HR 2.15), and RT (HR 2.12). However, use of a chemotherapy regimen similar to that for small cell lung cancer (SCLC) (HR 0.42) was associated with prolonged survival.

\section{Sensitivity analysis}

To assess the stability of each pooled result in our meta-analysis, we conducted a sensitivity analysis for each analysis by sequential omission of individual studies. There was no significant difference in the survival rates and prognostic factors.

\section{Publication bias analysis}

We used Beggar's and Egger's tests to examine potential publication bias among the studies. The two tests showed no evidence of statistical publication bias among the survival rates and prognostic factors.

\section{Discussion}

SCNEC survival rates

In recent decades, success has been achieved in the management of SCNEC. Nevertheless, SCNEC is still a malignant tumor with poor prognosis [4,17-20]. Our multicenter retrospective study revealed that the 5 -year OS rate for the 40 patients was $20 \%$ (Fig. 1), lower than the pooled 5-year OS rate of $37 \%$ in the meta-analysis (Fig. 2). The most likely reason for this significant difference between the clinical group and meta-analysis was the low incidence of SCNEC and limited number of patients. Moreover, compared with that of SCNEC, the 5-year OS rates of SCC and ADC were $74.3 \%$ and $64.6 \%$, respectively [21], which suggested that SCNEC was more malignant than the common types of cervical cancer.

The survival information gained from the present analysis can also help in the longterm fellow up of patients with SCNEC. In the meta-analysis, estimation of the pooled 2-year OS rate, 3 -year OS rate, and 5 -year OS rate were $62 \%, 35 \%$, and $35 \%$, respectively. The results suggest that about $40 \%$ of SCNEC deaths occurred within the second year following diagnosis and another $30 \%$ took place during the third year. Furthermore, it could mean that we should pay more attention to patients with SCNEC during the second year and third year after treatment and try to find the reason for the sudden declines in OS rate in the second year.

Estimations of the pooled 2-year DFS rate and 5-year DFS rate were respectively $48 \%$ and $35 \%$ in the meta-analysis. The results illustrate that more than half of SCNEC patients suffered recurrence within the second year following diagnosis and another $10 \%$ of patients had disease progression between the second year and the fifth year. From these results, due to the aggressive nature of SCNEC [22], distant micrometastasis must always be assumed to be present [23]. Hence, closer attention should be paid during the first 3 years after treatment.

Prognostic factors for SCNEC

The effects of tumors on prognostic factors, either by direct tumor extension or by distant metastasis, is a major challenge. If the tumor extends rapidly, prognosis is poor, even after treatment. Clinicopathologic factors, including tumor size, LVSI, DSI, surgical margins, and PI are frequently used to evaluate the prognosis of cervical cancer in common histologic types such as SCC, ADC, and adenosquamous carcinoma [7, 23-29]. However, relevant factors for SCNEC remain controversial. Our findings among the clinical group of 40 patients showed that only advanced FIGO stage tended to be associated with poor survival. To further identify other potential prognostic factors for SCNEC, we conducted a meta-analysis to generate a reliable estimation of potential prognostic factors for SCNEC (Table 4). The 


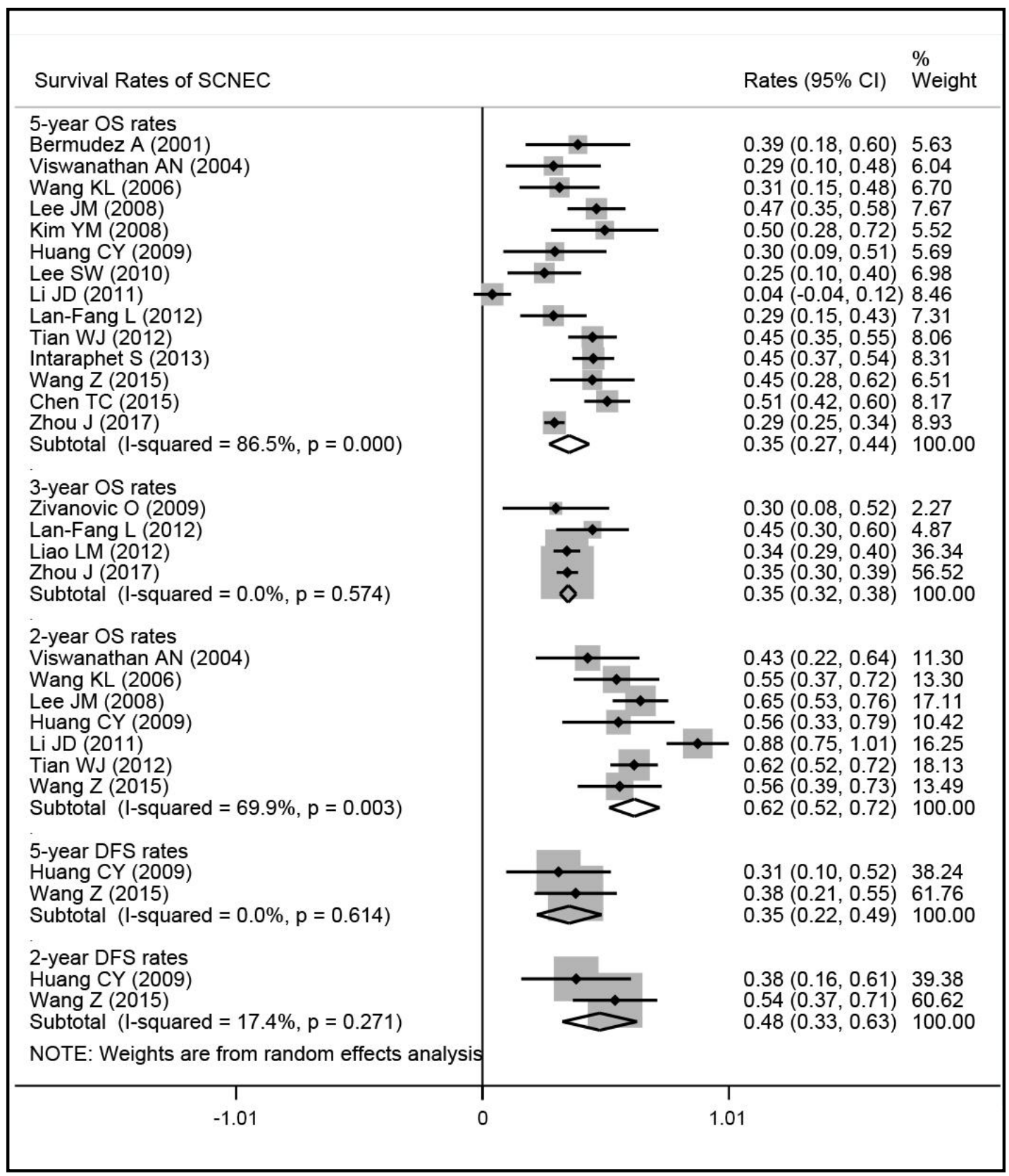

Fig. 2. Meta-analysis of the 2-year disease-free survival (DFS) rate, 5-year DFS rate, 2-year overall survival (OS) rate, 3-year OS rate and 5-year OS rate of SCNEC. The pooled 5-year OS rate from 14 studies was 35\%; the pooled 3-year OS rate from 4 studies was 35\%; the pooled 2-year OS rate from 7 studies was $62 \%$; the pooled 5-year DFS rate from 2 studies was 35\%; the pooled 2-year DFS rate from 2 studies was $48 \%$.

results demonstrated that advanced FIGO stage, larger tumor size, LNM (+), LVSI (+), DSI > $2 / 3$, and PI (+) were also associated with poor survival outcomes.

Based on the results of the retrospective study and meta-analysis, these factors, as in the case of common histologic types of cervical cancer, can also be used to evaluate the prognosis of SCNEC and contribute to the accurate assessment of the progress of the disease. Furthermore, treatment options should be chosen according to the prognostic factors. For example, the National Comprehensive Cancer Network (NCCN) guidelines recommend conservative treatment using conization for FIGO stage IA1 cervical cancer with LVSI (-). However, this option is not recommended for patients with the same stage but with LVSI $(+)$ 


\section{Cellular Physiology Cell Physiol Biochem 2018;50:1113-1122 \begin{tabular}{ll|l} 
DOl: 10.1159/000494538 & O 2018 The Author(s). Published by S. Karger AG, Basel \\
wwww.karger.com/cpb
\end{tabular} \\ Xu et al.: Clinicopathological Aspects of SCNEC}

[30]. Patients with SCNEC who have advanced FIGO stage, larger tumor size, (+) LNM, (+) LVSI, DSI $>2 / 3$, and/or PI $(+)$ should be managed with an alternative treatment modality to avoid recurrence and disease progression in the future.

Potential therapeutic approach for SCNEC

Currently, there is still no consensus on which modality should be the first-line treatment for SCNEC [31]. On the one hand, because of the similar features, the treatment strategy for SCNEC is essentially extrapolated from that for SCLC. VAC (vincristine, adriamycin, and cyclophosphamide) or EP (etoposide and cisplatin) regimens have frequently been used for SCNEC $[14,32]$. On the other hand, in China, radical surgery is the main treatment chosen by patients with SCNEC in early FIGO stages because of the recommendation of NCCN for the common types of cervical cancer [30]. As a result, SCNEC has always been treated with a combination of surgery, chemotherapy, and/or RT [33]. However, there is no consensus on the efficacy of treatment protocols.

The Society of Gynecologic Oncology (SGO) recommends that for cervical neuroendocrine tumors less than $4 \mathrm{~cm}$, radical hysterectomy with lymphadenectomy should be performed, with the option of adjuvant chemotherapy [29, 34]. However, some studies have questioned the efficacy of radical surgery for this rare disease $[4,11]$. Our findings in the clinical group suggest that radical surgery is associated with prolonged survival, and also support the SGO recommendation. As for chemotherapy, the conclusions of our meta-analysis demonstrate that chemotherapy regimens like VAC or PE, which are similar to those for SCLC, had a significantly favorable impact on survival. In contrast, RT was associated with poor survival in the clinical group of 40 patients and the meta-analysis of 1901 patients. The above discussion tentatively suggests that radical surgery combined with a chemotherapy regimen similar to one for SCLC (VAC or PE) may be a potential therapeutic approach for SCNEC. Although we are unable to accurately identify the treatment for SCNEC, our results provide a thorough description of the cohort to help determine the optimal treatment and we recommend that the final decision should be in accordance with the clinical impression.

\section{Limitations}

The present study had some limitations. First, the retrospective design and the lack of randomized prospective studies reduced the value of our conclusions. Future prospective studies are needed to determine the survival rates and prognostic factors more accurately. Second, the number of patients in the clinical group was small and it is hard to get a reliable estimation of survival rates and prognostic factors. As such, we performed a separate analysis comparing the results from our data of 40 patients with that of a meta-analysis, and this lends support to our results. Third, the potential for selection bias could not be completely eliminated as only English and Chinese literature was included in the meta-analysis. Moreover, we had to conduct a meta-analysis to identify the optimal potential therapeutic approach because of the limited data. It is hoped that more gynecological cancer centers will participate and cooperate in the search for more optimized and effective therapy regimens.

\section{Acknowledgements}

This work was supported by the National Natural Science Foundation of China (No. 81672589; 81302249); the National Key Research and Development Program of China (No. 2016 YFC1302901); and the Shenzhen Science and Technology Program (No. JCYJ20160429161218745).

\section{Disclosure Statement}

The authors declare no conflict of interests. 


\section{Cellular Physiology Cell Physiol Biochem 2018;50:1113-1122 \begin{tabular}{ll|l} 
and Biochemistry Published OnIIne: 24 October 2018 & $\begin{array}{l}\text { (c) } 2018 \text { The Author(s). Published by S. Karger AG, Basel } \\
\text { www.karger.com/cpb }\end{array}$ \\
\hline
\end{tabular}}

Xu et al.: Clinicopathological Aspects of SCNEC

\section{References}

1 Miller B, Dockter M, El TM, Photopulos G: Small cell carcinoma of the cervix: A clinical and flow-cytometric study. Gynecol Oncol 1991;42:27-33.

-2 Intaraphet S, Kasatpibal N, Siriaunkgul S, Chandacham A, Sukpan K, Patumanond J: Prognostic factors for small cell neuroendocrine carcinoma of the uterine cervix: An institutional experience. Int J Gynecol Cancer 2014;24:272-279.

3 Li JD, Zhuang Y, Li YF, Feng YL, Hou JH, Chen L, Zhu AN, Wu QL, Yun JP: A clinicopathological aspect of primary small-cell carcinoma of the uterine cervix: A single-centre study of 25 cases. J Clin Pathol 2011;64:1102-1107.

>4 Chen TC, Huang HJ, Wang TY, Yang LY, Chen CH, Cheng YM, Liou WH, Hsu ST, Wen KC, Ou YC, Hung YC, Lai HC, Ho CM, Chang TC: Primary surgery versus primary radiation therapy for FIGO stages I-II small cell carcinoma of the uterine cervix: A retrospective Taiwanese Gynecologic Oncology Group study. Gynecol Oncol 2015;137:468-473.

5 Maher J: A piece of my mind. Lack of data. JAMA 2012;308:1331-1332.

6 Huang CY, Chen YL, Chu TC, Cheng WF, Hsieh CY, Lin MC: Prognostic factors in women with early stage small cell carcinoma of the uterine cervix. Oncol Res 2009;18:279-286.

7 Chan JK, Loizzi V, Burger RA, Rutgers J, Monk BJ: Prognostic factors in neuroendocrine small cell cervical carcinoma: A multivariate analysis. Cancer 2003;97:568-574.

8 Cohen JG, Kapp DS, Shin JY, Urban R, Sherman AE, Chen LM, Osann K, Chan JK: Small cell carcinoma of the cervix: Treatment and survival outcomes of 188 patients. Am J Obstet Gynecol 2010;203:341-347.

-9 Wang Z, Wu L, Yao H, Sun Y, Li X, Li B, Zhang R, Ma S, Huang M: [Clinical analysis of 32 cases with neuroendocrine carcinoma of the uterine cervix in early-stage disease]. Zhonghua Fu Chan Ke Za Zhi 2015;50:198-203.

10 Liao LM, Zhang X, Ren YF, Sun XY, Di N, Zhou N, Pan RK, Ma SH, Zhou LX: Chromogranin a (CgA) as poor prognostic factor in patients with small cell carcinoma of the cervix: Results of a retrospective study of 293 patients. PLoS One 2012; 7:e33674.

11 Lee SW, Lim KT, Bae DS, Park SY, Kim YT, Kim KR, Nam JH: A multicenter study of the importance of systemic chemotherapy for patients with small-cell neuroendocrine carcinoma of the uterine cervix. Gynecol Obstet Invest 2015;79:172-178.

12 Lee SW, Nam JH, Kim DY, Kim JH, Kim KR, Kim YM, Kim YT: Unfavorable prognosis of small cell neuroendocrine carcinoma of the uterine cervix: A retrospective matched case-control study. Int J Gynecol Cancer 2010;20:411-416.

13 Tian WJ, Zhang MQ, Shui RH: Prognostic factors and treatment comparison in early-stage small cell carcinoma of the uterine cervix. Oncol Lett 2012;3:125-130.

14 Pei X, Xiang L, Ye S, He T, Cheng Y, Yang W, Wu X, Yang H: Cycles of cisplatin and etoposide affect treatment outcomes in patients with FIGO stage I-II small cell neuroendocrine carcinoma of the cervix. Gynecol Oncol 2017;147:589-596.

15 Lee JM, Lee KB, Nam JH, Ryu SY, Bae DS, Park JT, Kim SC, Cha SD, Kim KR, Song SY, Kang SB: Prognostic factors in FIGO stage IB-IIA small cell neuroendocrine carcinoma of the uterine cervix treated surgically: Results of a multi-center retrospective Korean study. Ann Oncol 2008;19:321-326.

-16 Tierney JF, Stewart LA, Ghersi D, Burdett S, Sydes MR: Practical methods for incorporating summary timeto-event data into meta-analysis. Trials 2007;8:16.

17 Viswanathan AN, Deavers MT, Jhingran A, Ramirez PT, Levenback C, Eifel PJ: Small cell neuroendocrine carcinoma of the cervix: Outcome and patterns of recurrence. Gynecol Oncol 2004;93:27-33.

18 Wang KL, Yang YC, Wang TY, Chen JR, Chen TC, Chen HS, Su TH, Wang KG: Neuroendocrine carcinoma of the uterine cervix: A clinicopathologic retrospective study of 31 cases with prognostic implications. J Chemother 2006;18:209-216.

19 Kim YM, Jung MH, Kim DY, Kim JH, Kim YT, Nam JH: Small cell carcinoma of the uterine cervix: Clinicopathologic study of 20 cases in a single center. Eur J Gynaecol Oncol 2009;30:539-542.

-20 Lan-Fang L, Hai-Yan S, Zuo-Ming Y, Jian-Qing Z, Ya-Qing C: Small cell neuroendocrine carcinoma of the cervix: Analysis of the prognosis and role of radiation therapy for 43 cases. Eur J Gynaecol Oncol 2012;33:68-73. 


\section{Cellular Physiology Cell Physiol Biochem 2018;50:1113-1122

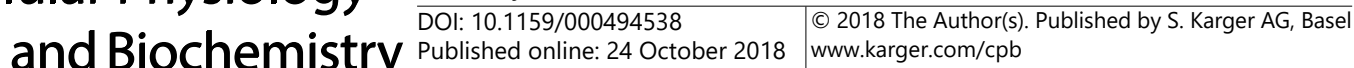 and Biochemistry $\frac{\text { Published online: } 24 \text { October } 2018}{\text { Xu et al.: Clinicopathological Aspects of SCNEC }}$}

21 Chen J, Macdonald OK, Gaffney DK: Incidence, mortality, and prognostic factors of small cell carcinoma of the cervix. Obstet Gynecol 2008;111:1394-1402.

-22 Kwon J, Eom KY, Kim IA, Kim JS, Kim YB, No JH, Kim K: Prognostic value of log odds of positive lymph nodes after radical surgery followed by adjuvant treatment in High-Risk cervical cancer. Cancer Res Treat 2016;48:632-640.

23 Wang Y, Mei K, Xiang MF, Li JM, Xie RM: Clinicopathological characteristics and outcome of patients with small cell neuroendocrine carcinoma of the uterine cervix: Case series and literature review. Eur J Gynaecol Oncol 2013;34:307-310.

-24 Small WJ, Bacon MA, Bajaj A, Chuang LT, Fisher BJ, Harkenrider MM, Jhingran A, Kitchener HC, Mileshkin LR, Viswanathan AN, Gaffney DK: Cervical cancer: A global health crisis. Cancer 2017;123:2404-2412.

-25 Ryu HS, Chun M, Chang KH, Chang HJ, Lee JP: Postoperative adjuvant concurrent chemoradiotherapy improves survival rates for high-risk, early stage cervical cancer patients. Gynecol Oncol 2005;96:490-495.

-26 Zivanovic O, Leitao MJ, Park KJ, Zhao H, Diaz JP, Konner J, Alektiar K, Chi DS, Abu-Rustum NR, Aghajanian C: Small cell neuroendocrine carcinoma of the cervix: Analysis of outcome, recurrence pattern and the impact of platinum-based combination chemotherapy. Gynecol Oncol 2009;112:590-593.

27 Kasamatsu T, Sasajima Y, Onda T, Sawada M, Kato T, Tanikawa M: Surgical treatment for neuroendocrine carcinoma of the uterine cervix. Int J Gynaecol Obstet 2007;99:225-228.

28 Hoskins PJ, Swenerton KD, Pike JA, Lim P, Aquino-Parsons C, Wong F, Lee N: Small-cell carcinoma of the cervix: Fourteen years of experience at a single institution using a combined-modality regimen of involvedfield irradiation and platinum-based combination chemotherapy. J Clin Oncol 2003;21:3495-3501.

29 Gardner GJ, Reidy-Lagunes D, Gehrig PA: Neuroendocrine tumors of the gynecologic tract: A Society of Gynecologic Oncology (SGO) clinical document. Gynecol Oncol 2011;122:190-198.

-30 Koh WJ, Greer BE, Abu-Rustum NR, Apte SM, Campos SM, Cho KR, Chu C, Cohn D, Crispens MA, Dorigo O, Eifel PJ, Fisher CM, Frederick P, Gaffney DK, Han E, Huh WK, Lurain JR, Mutch D, Fader AN, Remmenga SW et al.: Cervical Cancer, Version 2.2015. J Natl Compr Canc Netw 2015;13:395-404.

-31 Zhou J, Yang HY, Wu SG, He ZY, Lin HX, Sun JY, Li Q, Guo ZW: The local treatment modalities in FIGO stage I-II small-cell carcinoma of the cervix are determined by disease stage and lymph node status. Cancer Med 2016;5:1108-1115.

32 Kalemkerian GP, Akerley W, Bogner P, Borghaei H, Chow LQ Downey RJ, Gandhi L, Ganti AK, Govindan R, Grecula JC, Hayman J, Heist RS, Horn L, Jahan T, Koczywas M, Loo BJ, Merritt RE, Moran CA, Niell HB, O’Malley J et al.: Small cell lung cancer. J Natl Compr Canc Netw 2013;11:78-98.

33 McCann GA, Boutsicaris CE, Preston MM, Backes FJ, Eisenhauer EL, Fowler JM, Cohn DE, Copeland LJ, Salani R, O'Malley DM: Neuroendocrine carcinoma of the uterine cervix: The role of multimodality therapy in early-stage disease. Gynecol Oncol 2013;129:135-139.

-34 Satoh T, Takei Y, Treilleux I, Devouassoux-Shisheboran M, Ledermann J, Viswanathan AN, Mahner S, Provencher DM, Mileshkin L, Avall-Lundqvist E, Pautier P, Reed NS, Fujiwara K: Gynecologic Cancer InterGroup (GCIG) consensus review for small cell carcinoma of the cervix. Int J Gynecol Cancer 2014;24:S102-S108.

35 Chang TC, Lai CH, Tseng CJ, Hsueh S, Huang KG, Chou HH: Prognostic factors in surgically treated small cell cervical carcinoma followed by adjuvant chemotherapy. Cancer 1998;83:712-718.

36 Bermudez A, Vighi S, Garcia A, Sardi J: Neuroendocrine cervical carcinoma: A diagnostic and therapeutic challenge. Gynecol Oncol 2001;82:32-39.

-37 Kuji S, Hirashima Y, Nakayama H, Nishio S, Otsuki T, Nagamitsu Y, Tanaka N, Ito K, Teramoto N, Yamada $\mathrm{T}$ : Diagnosis, clinicopathologic features, treatment, and prognosis of small cell carcinoma of the uterine cervix; Kansai Clinical Oncology Group/Intergroup study in Japan. Gynecol Oncol 2013;129:522-527.

38 Huang L, Liao LM, Liu AW, Wu JB, Cheng XL, Lin JX, Zheng M: Analysis of the impact of platinum-based combination chemotherapy in small cell cervical carcinoma: A multicenter retrospective study in Chinese patients. BMC Cancer 2014;14:140.

39 Wang Z, Wu L, Yao H, Sun Y, Li X, Li B, Zhang R, Ma S, Huang M: Clinical analysis of 32 cases with neuroendocrine carcinoma of the uterine cervix in early-stage disease. Zhonghua Fu Chan Ke Za Zhi 2015;50:198-203.

-40 Zhou J, Wu SG, Sun JY, Tang LY, Lin HX, Li FY, Chen QH, Jin X, He ZY: Clinicopathological features of small cell carcinoma of the uterine cervix in the surveillance, epidemiology, and end results database. Oncotarget 2017;8:40425-40433. 